\title{
HUBUNGAN DUKUNGAN SOSIAL TEMAN SEBAYA DENGAN MOTIVASI BELAJAR SISWA SMA X LAMPUNG BARAT SELAMA PANDEMI COVID-19
}

\section{THE RELATIONSHIP OF SOCIAL SUPPORT OF PEOPLE WITH THE LEARNING MOTIVATION OF STUDENTS OF SMA X LAMPUNG BARAT DURING THE COVID-19 PANDEMIC}

\author{
Setriani1, Meilia Ishar ${ }^{2}$ \& Fatimah Zahra ${ }^{3}$ \\ Fakultas Psikologi Universitas Muhammadiyah Lampung \\ setriani.ria@gmail.com,meilia.ishar@gmail.com,98fatimah.zahra@gmail.com
}

\begin{abstract}
Motivation is the driving force that moves a person's soul, encouraging someone to develop themselves and mobilize all the abilities and energy they have in order to achieve maximum performance. The purpose of this study was to determine whether there was a relationship between peer support and learning motivation of X high school students in West Lampung during the pandemic. One that affects student learning motivation is the existence of social support from peers, peers have an important role in adolescent development, especially at the stage of learning development where adolescents who have many friends will be able to increase interest in their education. The sample of this study amounted to 118 students in grades 1 and 2 of high school. people with the data analysis method used is the Pearson Product Moment correlation method. The results of the correlation coefficient value of the correlation coefficient of 0.685 indicate a relationship between the variables of peer social support on student motivation during the Pandemic.
\end{abstract}

Keywords: social support, learning motivation, pandemic, peers

\begin{abstract}
ABSTRAK
Motivasi belajar merupakan daya penggerak yang memotivasi semangat seseorang, mendorong seseorang untuk mengembangkan diri dan menggerakkan semua kemampuan serta energi yang dimilikinya demi mencapai prestasi yang maksimal. Tujuan penelitian adalah untuk mengetahui apakah ada hubungan antara dukungan teman sebaya dengan motivasi belajar siswa SMA X di Lampung Barat selama masa Pandemi. Salah satu yang mempengaruhi motivasi belajar siswa adalah adanya dukungan sosial dari teman sebaya. Teman sebaya memiliki peran penting dalam perkembangan remaja terutama pada tahapan perkembangan belajar dimana remaja yang banyak memiliki teman akan mampu meningkatkan minat terhadap pendidikannya. Sampel penelitian ini berjumlah 118 siswa kelas 1 dan 2 SMA dengan metode korelasi Pearson Product Moment. Hasil koefisien korelasi sebesar 0.685 menunjukan adanya hubungan positif antara variabel dukungan sosial teman sebaya terhadap motivasi belajar siswa dimasa pandemi.
\end{abstract}

Kata kunci: dukungan sosial, motivasi belajar, pandemic, teman sebaya 


\section{PENDAHULUAN}

Pendidikan merupakan salah satu upaya mmemajukan Negara. Suatu negara akan berkembang dan maju jika masyarakatnya terpelajar. Tujuan Pendidikan termaktub dalam dalam Undang-undang No. 20 Pasal 3 tahun 2003 untuk mengembangkan kemampuan dan membentuk watak yang dapat mengembangkan potensi peserta didik agar menjadi manusia yang beriman, berilmu, cakap, kreatif, mandiri dan menjadi warga negara yang demokratis serta bertanggung jawab.

Proses belajar menurut Reber (dalam Muhibbin, 1995) adalah tercapainya suatu hasil dan beberapa perubahan setelah melakukan cara-cara khusus. Proses belajar yang efektif, kondusif dan penuh dengan semangat akan dapat mencapai tujuan belajar. Salah satu definisi belajar dikemukakan oleh Aunurrahman (2010) sebagai usaha yang dilakukan oleh individu dalam perubahan tingkah laku baik melalui latihan dan pengalaman yang menyangkut aspek-aspek kognitif, afektif dan psikomotorik.

Pandemi Covid-19 (Coronavirus Disease 2019) saat ini tengah melanda dunia, tentunya mempengaruhi proses belajar yang sudah berjalan. Situasi ini menyebabkan proses belajar tidak dapat dilakukan seperti biasanya, karena siswa tidak dapat bertatap muka secara langsung dengan tenaga pendidik. Penyakit ini muncul pertama kali pada akhir tahun 2019 di Wuhan, Provinsi Hubei, Cina (Li, Liu, Yu, Tang, \& Tang, 2020). Penyakit Covid-19 berasal dari virus SARS-CoV-1 yang ditetapkan namanya pada 11 Februari 2020 (Gorbalenya et al., 2020). Pada 11 Maret 2020 WHO juga menetapkan Covid-19 sebagai pandemi karena penyebarannya yang sangat pesat hingga 13 kali lipat diluar Cina.

Pandemi ini berdampak pada aspek pendidikan. Terdapat sekitar 1.725 miliar pelajar saat ini terkena dampak karena penutupan sekolah sebagai respon terhadap pandemi UNISCO (dalam Nurkholis, 2020). Sampai saat ini jumlah kasus Covid-19 masih terus bertambah termasuk di Indonesia. Dalam website resmi Kementerian RI jumlah kasus Covid-19 di Indonesia sampai tanggal 22 Juli 2020 mencapai 91.751 kasus, jumlah meninggal dunia akibat Covid-19 hingga 4.459 jiwa. Sebagai upaya dalam pencegahan Covid-19 Menteri Pendidikan dan Kebudayaan (Mendikbud) Nadiem Anwar Makarim menyampaikan Surat Edaran Nomor 4 Tahun 2020 yang menghimbau agar Lembaga Pendidikan dapat melakukan pembelajaran di rumah sampai waktu yang ditentukan. Hal 
ini dilakukan untuk memutus rantai penyebaran Covid-19, sebagai gantinya kegiatan pembelajaran dilakukan secara online untuk semua jenjang Pendidikan.

Situasi Pandemi Covid-19 menuntut para siswa untuk belajar di rumah dengan fasilitas yang ada. Wawancara yang dilakukan kepada siswa siswi SMA X Lampung Barat, didapatkan informasi bahwa menurut siswa pembelajaraan di rumah dirasakan kurang menyenangkan. Pembelajaran dengan sistem daring menjadi hambatan bagi siswa karena pengalaman, kemampuan dan fasilitas yang berbeda-beda. Tugas-tugas yang diberikan tenaga pendidik terlalu banyak dan tanpa jeda, selain itu mereka juga tidak bisa mengerjakan bersama dengan teman sebayanya. Waktu berkumpul juga menjadi terbatas sehingga siswa lebih banyak menghabiskan waktu dirumah sendiri.

Siswa SMA X Lampung Barat sebelumnya menghabiskan waktu 6-8 jam di sekolah. Pada jam tersebut mereka biasa melakukan kegiatan dalam kelompok, bergaul, berdiskusi dengan banyak teman yang memiliki beragam karakter, menyelesaikan persoalan dengan tanya jawab secara langsung. Pembelajaran dirumah menjadi membosankan karena tidak dapat dilakukan bersama teman sebaya lainnya. Selama masa pandemic Siswa SMA X Lampung Barat menjadi jarang berinteraksi langsung dengan teman-temannya, mereka lebih banyak berinteraksi secara online dengan menggunakan media whatsapp, instragram, dan facebook.

Selain itu semenjak pandemi pembelajaran di rumah menjadi kurang efektif, salah satunya disebabkan karena aturan yang tidak konsisten dan tidak pasti. Aturan-aturan dapat mendisiplinkan siswa dalam belajar misalnya menentukan kapan waktu belajar dan waktu istirahat. Belajar di rumah tanpa memperhatikan aturan membuat siswa kurang disiplin dan menggunakan waktunya tidak untuk belajar. Banyaknya fasilitas hiburan dirumah dapat dengan mudah mengalihkan perhatian siswa, misalnya televisi, film, game, dan lain-lain.

Ketidakpahaman terhadap teknologi sebagai sarana belajar yang digunakan juga menjadi persoalan yang menganggu siswa, kurangnya pengetahuan mengenai materi bahan mengajar siswa dapat membuat siswa enggan bertanya sehingga dapat menimbulkan penurunan motivasi belajar (Nurkholis, 2020).

Penurunan motivasi belajar menyebabkan perasaan lelah, rasa ingin menyerah, berhenti, yang berkaitan dengan motivasi belajar siswa. Motivasi belajar adalah daya 
penggerak dalam diri siswa yang memunculkan kegiatan belajar, menjamin kelangsungan kegiatan belajar, sehingga tujuan yang dikehendaki oleh siswa dalam belajar dapat tercapai (Decy \& Ryan, 2000).

Motivasi belajar berasal dari faktor internal dan eksternal. Motivasi belajar dari faktor internal terbentuk karena kesadaran diri atas pemahaman betapa pentingnya belajar untuk mengembangkan dirinya. Motivasi belajar dari faktor eksternal, yaitu dapat berupa rangsangan dari orang lain, keluarga dan dukungan sosial teman sebaya yang dapat mepengaruhi psikologis orang yang bersangkutan (Nelson \& De Backer, 2008).

Dukungan sosial teman sebaya didapatkan dengan berinteraksi bersama teman sebayanya. Dukungan sosial teman sebaya menurut Tracy dan Whittaker (1990) adalah tindakan orang lain lakukan ketika mereka menyampaikan bantuan. Interaksi dengan teman sebaya juga dapat mengajarkan tentang perilaku kerjasama, tolong menolong, kompetisi dan kemampuan sosial yang akan menunjang motivasi belajar (Novianti 2009).

Penelitian mengenai hubungan dukungan sosial teman sebaya dengan motivasi belajar pernah diteliti oleh Sofiatri Titi Hidayati, tahun 2016 di kota Malang. Penelitian tersebut menghasilkan korelasi antara dukungan sosial teman sebaya dengan motivasi belajar adalah 0,474 dengan taraf signifikan sebesar 0,000 dan arah hubungan adalah positif, artinya semakin tinggi dukungan sosial teman sebaya maka semakin tinggi motivasi belajar siswa. Penelitian lainnya mengenai Hubungan Dukungan Sosial Teman Sebaya dengan Motivasi Belajar SMAN 5 kota Semarang oleh Novianti, 2009, Hasil analisis regresi menunjukkan adanya hubungan positif yang signifikan antara dukungan sosial teman sebaya dan motivasi belajar. Dukungan sosial teman sebaya memberikan sumbungan efektif sebesar $25 \%$ terhadap motivasi belajar.

Perbedaan penelitian ini dari penelitian sebelumnya terdapat pada situasi pandemi Covid-19 yang menyebabkan siswa melakukan kegiatan belajar dirumah dan menyebabkan interaksi secara langsung dengan teman sebaya berkurang. Melihat fenomena tersebut peneliti tertarik untuk meneliti mengenai "Hubungan Dukungan Sosial Teman Sebaya dengan Motivasi Belajar siswa SMA X Lampung Barat Selama Pandemi Covid-19". 


\section{METODE PENELITIAN}

Pada penelitian ini, peneliti menggunakan probability sampling dengan teknik sampling sistematis. Sampling sistematis adalah teknik pengambilan sampel berdasarkan urutan dari anggota yang telah diberikan nomor urut. Dari 118 populasi yang ada, peneliti mengambil nomor dengan kelipatan dua, sehingga didapatkan sampel berjumlah 59 sampel.

Skala yang digunakan dalam penelitian ini adalah skala yang diturunkan dari teori Dukungan Sosial menurut Tracy (1990). Dukungan Sosial meliputi aspek dukungan emosional, dukungan informasional, dan dukungan konkrit dengan total item 54 . Motivasi Belajar diukur dengan skala motivasi belajar yang disusun oleh Nurul Hikmah (2012) berdasarkan aspek yang diturunkan dari teori Decy \& Ryan (2000) yang terdiri dari aspek regulasi eksternal, regulasi introjeksi, regulasi identifikasi terdapat 12 item favorable dan 12 item unfavorable sehingga berjumlah keseluruhan 48 item.

\section{HASIL PENELITIAN}

Hasil asumasi adalah uji persyarat yang dilakukan untuk melihat apakah pengujian terhadap asumsi-asumsi yang dihasilkan sudah terpenuhi atau belum sehingga data dapat dianalisis lebih lanjut. Uji normalitas yang dimaksud adalah untuk menguji apakah variabel terdistribusi secara normal. Uji normalitas dilakukan dengan menggunakan teknik One Sample Kolmogorov-Smirnov. Berdasarkan analisis data dengan bantuan program SPSS 25.0 dapat di ketahui nilai signifikan yang menunjukkan normalitas data kriteria yang digunakan yaitu data dikatakan berdistribusi normal, jika harga koefesien Asymp, Sig pada output Kolomogorov-Smirnov test > dari alpha yang ditentukan yaitu 5\% (0.05). Hasil uji normalitas pada penelitian ini adalah sebagai berikut: 
Tabel 1. Hasil Uji Normalitas

\begin{tabular}{|c|c|c|}
\hline & & \begin{tabular}{|l} 
Unstandardized \\
Residual
\end{tabular} \\
\hline $\begin{array}{l}\mathrm{N} \\
\text { Normal Parameters a,b }\end{array}$ & $\begin{array}{l}\text { Mean } \\
\text { Std. } \\
\text { Deviation }\end{array}$ & \begin{tabular}{|l}
54 \\
.0000000 \\
14.98840262
\end{tabular} \\
\hline $\begin{array}{l}\text { Most Extreme } \\
\text { Differences } \\
\text { Test Statistic } \\
\text { Asymp. Sig. (2-tailed) }\end{array}$ & $\begin{array}{l}\text { Absolute } \\
\text { Positive } \\
\text { Negative }\end{array}$ & $\begin{array}{l}.064 \\
.064 \\
-.039 \\
.064 \\
.200^{\mathrm{c}, \mathrm{d}} \\
\end{array}$ \\
\hline
\end{tabular}

\footnotetext{
a. Test distribution is Normal.

b. Calculated from data.

c. Lilliefors Significance Correction.

$\mathrm{d}$. This is a lower bound of the true significance.
}

Berdasarkan hasil analisis yang dilakukan menggunakan aplikasi SPSS versi 25.0 kedua skala tersebut terbukti memiliki sebaran yang normal. Nilai Asymp. Sig sebesar 0,163 menjelaskan bahwa skala motivasi belajar dan skala dukungan sisoal teman sebaya memiliki sebaran normal $(0.163 ; \mathrm{p}>0.05)$.

Uji linearitas di lakukan untuk mengetahui hubungan antar variabel dependen dengan variabel independen. Uji linearitas dalam penelitian ini menggunakan uji linearitas dengan bantuan program SPSS 25.0. Dapat diketahui jika Sig. linearity lebih kecil dari taraf signifikansi yang dipakai yaitu $<0.05$ berarti berkorelasi linear. Dan dapat dilihat pada Sig. Deviation from Linearity untuk menunjukkan seberapa jauh model kita menyimpang dari model linier dengan melihat ( $p>0.05)$ maka model dalam penelitian dapat dikatakan linier. Berikut tabel hasil uji linearitas pada penelitian, sebagai berikut: 
Tabel 2. Uji Linearitas Dukungan Teman Sebaya Dengan Motivasi Belajar

\begin{tabular}{|c|c|c|c|c|c|c|c|}
\hline & & & $\begin{array}{l}\text { Sum } \\
\text { Squares }\end{array}$ & Df & $\begin{array}{l}\text { Mean } \\
\text { Square }\end{array}$ & $\mathrm{F}$ & Sig. \\
\hline \multirow{5}{*}{$\begin{array}{l}\text { MB * } \\
\text { DTS }\end{array}$} & \multirow{3}{*}{$\begin{array}{l}\text { Between } \\
\text { Groups }\end{array}$} & (Combined) & 2690,000 & 29 & 92,759 & 1,816 &, 070 \\
\hline & & Linearity & 1858,142 & 1 & 1858,142 & 36,375 &, 000 \\
\hline & & $\begin{array}{l}\text { Deviation } \\
\text { from } \\
\text { Linearity }\end{array}$ & 831,858 & 28 & 29,709 & ,582 & ,916 \\
\hline & Within Gr & & 1226,000 & 24 & 51,083 & & \\
\hline & Total & & 3916,000 & 53 & & & \\
\hline
\end{tabular}

Berdasarkan tabel diatas didapatkan nilai deviation from linearity sebesar 0.916>0.05 sehingga dapat disimpulkan bahwa variabel motivasi belajar dengan Dukungan sosial teman sebaya terbukti linear.

Hipotesis dalam penelitian ini adalah "ada hubungan yang signifikan antara dukungan sosial teman sebaya dengan motivasi belajar Siswa SMA X Lampung Barat selama pandemi Covid-19". Uji hipotesis dalam penelitian ini dilakukan dengan analisis regresi linear dalam aplikasi SPSS versi 25.0.

Tabel 3. Hasil Uji Korelasi

\begin{tabular}{|ll|l|l|}
\hline & MB & DTS \\
\hline MB & $\begin{array}{l}\text { Pearson } \\
\text { Correlation } \\
\text { Sig. (2-tailed) } \\
\text { N }\end{array}$ & 1 & $.685^{* *}$ \\
& 54 & $\begin{array}{l}.000 \\
54\end{array}$ \\
\hline DTS & $\begin{array}{l}\text { Pearson } \\
\text { Correlation } \\
\text { Sig. (2-tailed) } \\
\text { N }\end{array}$ & $.685^{* *}$ & 1 \\
& .000 & \\
\end{tabular}

Berdasarkan dari hasil analisis data diatas didapatkan nilai koefisien korelasi sebesar 0.685 dengan nilai signifikan 0.000 dimana $\mathrm{p}<0.05$ maka dapat disimpulkan bahwa adanya hubungan yang signifikan antara motivasi belajar dengan dukungan sosial teman sebaya SMA X Lampung Barat. Semakin tinggi dukungan sosial teman sebaya maka semakin tinggi motivasi belajar. Hipotesis awal diterima. 
Menurut Sugiyono, interpretasi serta analisis bagi koefisien korelasi yaitu 0.000.199 korelasi sangat rendah, 0.20-0.399 korelasi rendah, 0.40-0.599 korelasi sedang, 0,60-0.799 korelasi kuat, 0.80-1.00 korelasi sangat kuat. Dalam penelitian ini didapatkan nilai korelasi sebesar 0.689 menunjukkan bahwa kedua variabel tersebut memiliki hubungan korelasi kuat.

\section{DISKUSI}

Diketahui bahwa ada hubungan yang signifikan antara motivasi belajar dengan dukungan sosial teman sebaya SMA X Lampung Barat Semakin tinggi dukungan sosial teman sebaya maka semakin tinggi motivasi belajar. Hasil ini sejalan dengan penelitian yang dilakukan oleh Novianti, T. Mengenai Hubungan Dukungan Sosial Teman Sebaya dengan Motivasi Belajar siswa kelas VII MTS Al Yasini Pasuruan, pada tahun 2016.

Penelitian lain yang mendukung dilakukan di tahun 2017, oleh Addin yang berjudul "Hubungan antara Regulasi Diri dan Dukungan Sosial Teman Sebaya dengan Motivasi Berprestasi Siswa Kelas XI SMK Analisis Kesehatan Nasional Surakarta” yang menyatakan bahwa terdapat hubungan yang positif dan signifikan antara regulasi diri dan dukungan sosial teman sebaya dengan motivasi berprestasi. Sundari (2010) menjelaskan bahwa remaja yang mendapat dukungan emosional dari teman sebaya akan merasa dirinya dicintai, diperhatikan sehingga meningkatkan rasa harga diri. Seseorang dengan harga diri yang tinggi cenderung memiliki rasa kepercayaan diri yang tinggi, keyakinan diri bahwa remaja awal mampu menguasai situasi dan memberikan hasil yang positif baik dalam mengatasi permasalahan ataupun mencapai sebuah prestasi.

\section{KESIMPULAN DAN SARAN}

Berdasarkan hasil penelitian, dapat disimpulkan bahwa terdapat hubungan yang signifikan antara motivasi belajar dengan dukungan sosial teman sebaya di SMA X Lampung Barat. Hal ini berarti dukungan sosial dari teman sebaya menentukan motivasi belajar siswa di SMA tersebut. Kebersamaan dan dukungan sesame siswa mampu meningkat motivasi mereka dalam belajar. Oleh karenanya perlu di fasilitasi oleh sekolah kegiatan yang melibatkan kebersamaan mahasiswa di masa pandemi dengan tetap memperhatikan protocol kesehatan. Selain itu pengembangan motivasi intrinsic (dari dalam diri) melalui kegiatan pembelajaran juga disarankan. Motivasi ekstrinsik melalui 
teman sebaya dan motivasi intrinsik diperlukan agar prestasi belajar siswa menjadi lebih optimal. Saran untuk penelitian selanjutnya agar memperbanyak sampel penelitian agar lebih menggambarkan factor yang mempengaruhi motivasi siswa selama masa pandemic khususnya di Provinsi Lampung.

\section{DAFTAR PUSTAKA}

Aunurrahman. 2010. Belajar dan Pembelajaran, Cetakan ke-4. Bandung: Alfabeta.

Addin, R.A. (2017). Hubungan antara Regulasi Diri dan Dukungan Sosial Teman Sebaya dengan Motivasi Berprestasi Siswa Kelas XI SMK Analisis Kesehatan Nasional Surakarta.

Chen, H., Xu, W., Paris, C., Reeson, A., \& Li, X. (2020). Social distance and SARS memory: impact on the public awareness of 2019 novel coronavirus (COVID-19) outbreak. MedRxiv, 2020.03.11.20033688. https://doi.org/10.1101/2020.03.11.20033688

Dio Wira Pratama, Diana Rusmawati. 2018. Hubungan Dukungan Sosial Teman Sebaya Dengan Motivasi Belajar Dalam Program Sekolah Lima Hari Di Sman 5 Semarang.

Kementrian Pendidikan dan Kebudayaan Sikapi COVID-19, Kemendikbud Terbitkan Dua Surat Edaran 12 Maret 2020

Lu, R., Zhao, X., Li, J., Niu, P., Yang, B., Wu, H., ... Tan, W. (2020). Genomic characterisation and epidemiology of 2019 novel coronavirus: implications for virus origins and receptor binding. The Lancet, 395(10224), 565574.https://doi.org/10.1016/S0140-6736(20)30251-8

Muhibbin Syah, 1995. Psikologi Pendidikan dengan pendekatan baru. Bandung: Rosdakarya.

Nurkholis, 2020. Dampak Pandemi Novel-Corona Virus Disiase (Covid-19) Terhadap Psikologi Dan Pendidikan Serta Kebijakan Pemerintah: Jurnal PGSD Universitas Muhammadiyah Cirebon. Vol 6. Diakses pada 15 Mei 2020.

Nelson, R. M., \& DeBracker, T. K. (2008). Achievement motivation in adolescents: the role ofpeer climate and best friends. The Journal of Experimental Education.

Novianti, T. Hubungan Dukungan Sosial Teman Sebaya dengan Motivasi Belajar siswa kelas VII MTS Al Yasini Pasuruan. 2016.

Ryan \& Decy. 2000 Intrinsic and Extrinsic Motivations: Classic Definitions and New Directions.

Suemanto, Wasty. 2006. Psikologi Pendidikan. Jakarta: PT Asdi Mahasatya. 
